\title{
Solving the problem of air quality in Indian cities by retrofitting the EGR
}

This paper touches problem of transportation pollution focusing on $N O_{x}$ reducing in the India. There were India country chosen for study as the second populated country and most polluted cities in the world. As from statistics, it is known that more than $65 \%$ of Indian cars are old and they are the main reason of air pollution. Most of the old cars do not have any control measures for eliminating deadliest gases. Dumping the old cars is not possible, as the poor owns most of the old cars. For eliminating the pollution from old cars, the possible remedy is to control the emission of pollutants. Comparing to all gases in exhaust, nitrogen oxides are the dangerous one. It can may cause up to death. The best method to control the $N O_{x}$ gas is EGR (Exhaust Gas Recirculation) valves. This research mainly focuses on the possible ways of installing EGR in old engines and fabricate an EGR in one of the Indian cars. Maruti Suzuki 800 is best of for fabricating EGR, as it is a base model and most sold Indian car. As the result, there tremendous decreasing in NO $\mathrm{N}_{x}$ emission also the emission $\mathrm{CO}_{2}$ was reduced. The investigation about fabricating EGR in old vehicle results a positive output after calculated the cost of the fabrication, time consumption, work challenges and other facts. As Indian government adopt this concept, they can reduce the pollution from all types of vehicles to a great extend in few years of time with low investment.

Key words: engine pollution, retrofitting, EGR

\section{Introduction}

Nitrogen oxides $\left(\mathrm{NO}_{\mathrm{x}}\right)$ is common name for the chemical compounds group of oxides of nitrogen, which are highly reactive. Nitrous acids and nitric acid are also belonging to this group. Combustion of transportation fuel is the main reason for $\mathrm{NO}_{\mathrm{x}}$ formation. All types of cars, power plants and off-road equipment have a major role in $\mathrm{NO}_{\mathrm{x}}$ formation. There are a lot of harmful effects on human health as well as entire environment. $\mathrm{NO}_{\mathrm{x}}$ responds with ammonia, moisture and different mixes to shape nitric corrosive vapor and related particles. Little particles can infiltrate profoundly into delicate lung tissue and harm it causing sudden death in outrageous cases. Inward breath of these particles might cause or decline respiratory illnesses as bronchitis for example. $\mathrm{NO}_{\mathrm{x}}$ responds with volatile organic compounds with the vision of sunlight to frame and to obliterate ozone. Ozone can cause unfavorable impacts, for example, harm to lung tissue and diminishment in lung work for the most part in week persons (kids, elderly, and asthmatics). $\mathrm{NO}_{\mathrm{x}}$ additionally promptly responds with common organic chemicals to frame a wide assortment of dangerous items: nitroarenes, nitrosamines and furthermore, some of the nitrate radical may cause DNA mutation. As of late, another pathway, by means of $\mathrm{NO}_{\mathrm{x}}$, to ozone discovered that prevalently happens in beachfront regions through development of nitryl chloride when $\mathrm{NO}_{\mathrm{x}}$ encounters salt mist. $\mathrm{NO}_{\mathrm{x}}$ emissions likewise cause worldwide cooling through the arrangement of $\mathrm{OH}$ radicals that devastate methane atoms, countering the impact of ozone harming substances. The impact can be critical. The extreme goal of maximum $\mathrm{NO}_{\mathrm{x}}$ is to wind up in the soil as nitrate or nitrite, which are valuable to developing plants.

$\mathrm{NO}_{\mathrm{x}}$ and other $\mathrm{NO}_{\mathrm{x}}$ associate with water, oxygen and different synthetic compounds in the atmosphere to shape acid rain. Acid rain hurts delicate biological systems, for example, lakes and backwoods. Acid rain comes about when sulfur dioxide $\left(\mathrm{SO}_{2}\right)$ and nitrogen oxides $\left(\mathrm{NO}_{\mathrm{x}}\right)$ are discharged into the atmosphere and transported by wind and air streams. The $\mathrm{SO}_{2}$ and $\mathrm{NO}_{\mathrm{x}}$ respond with water, oxygen and different synthetic substances to frame sulfuric and nitric acids. These then blend with water and different materials previously tumbling to the ground. The nitrate particles that outcome from $\mathrm{NO}_{\mathrm{x}}$ make the air cloudy and hard to see however. Haze is caused when daylight experiences small pollution particles noticeable all around, which decrease the clearness and shade of what we see, particularly humid conditions $[7,9,11,16,18]$.

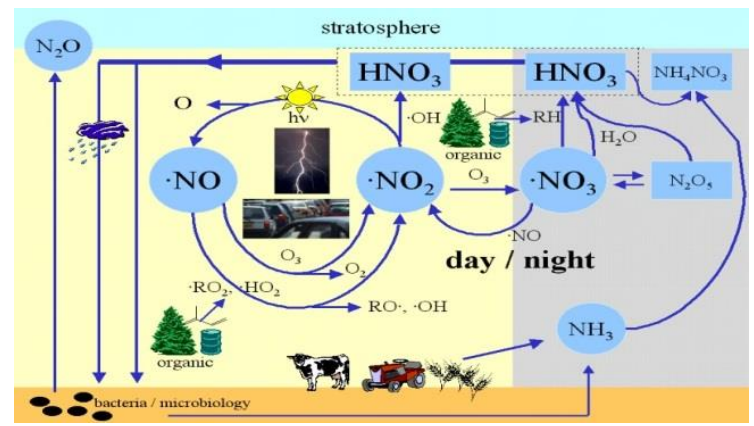

Fig. 1. Environmental effects of $\mathrm{NO}_{\mathrm{x}}[12]$

When world zones be studied due to $\mathrm{NO}_{\mathrm{x}}$ contamination it can be observed some differences in level of it - see Fig. 2.

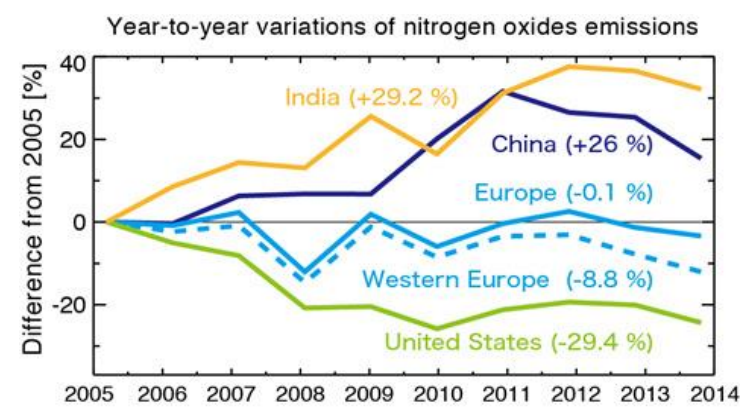

Fig. 2. Year-to-year variations of $\mathrm{NO}_{\mathrm{x}}[19]$ 
Focusing on European Union countries it can be found that for example during 2011 road transport and energy production are the prime sources of $\mathrm{NO}_{\mathrm{x}}$ emissions - Fig. 3 .

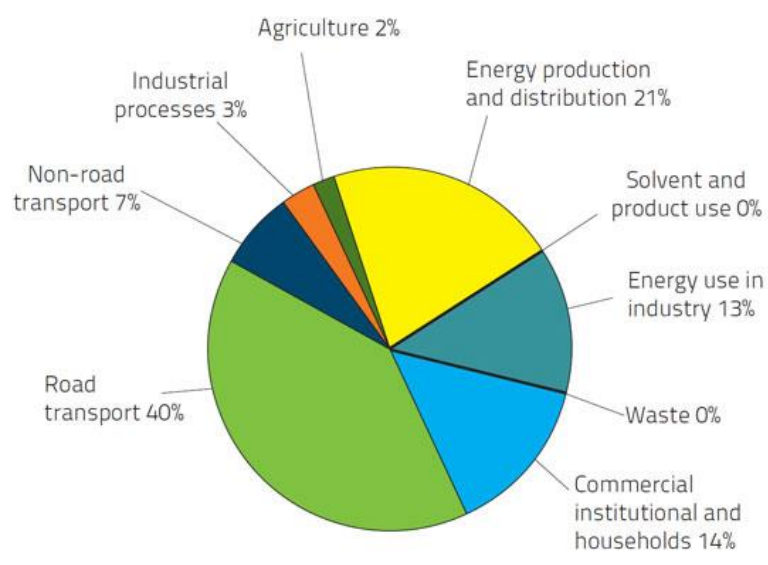

Fig. 3. $\mathrm{NO}_{\mathrm{x}}$ emissions in the EU during 2011 [5]

Similar situation was in USA, when during 2010 road transport and energy production are the prime sources for emission of $\mathrm{NO}_{\mathrm{x}}-$ Fig. 4.

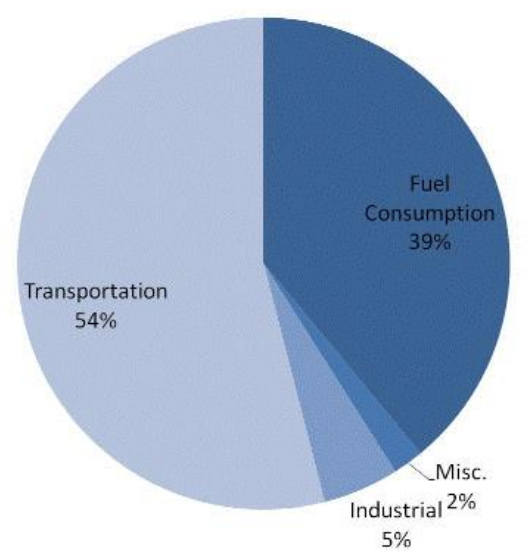

Fig. 4. $\mathrm{NO}_{\mathrm{x}}$ emissions in the USA during 2010 [4]

And in India, the quantity of urban cities where the guidelines of nitrogen oxides $\left(\mathrm{NO}_{\mathrm{x}}\right)$ surpassed standards expanded from $18 \%$ to $29 \%$ out of 10 years, as indicated by the Center for Science and Environment - Fig. 5.

In 2007, none of the Indian urban cities was in the basic class - that is 1.5 times as far as possible. In $2016,12 \%$ of the urban communities where $\mathrm{NO}_{\mathrm{x}}$ was being checked entered the basic rundown $[8,14,15]$.
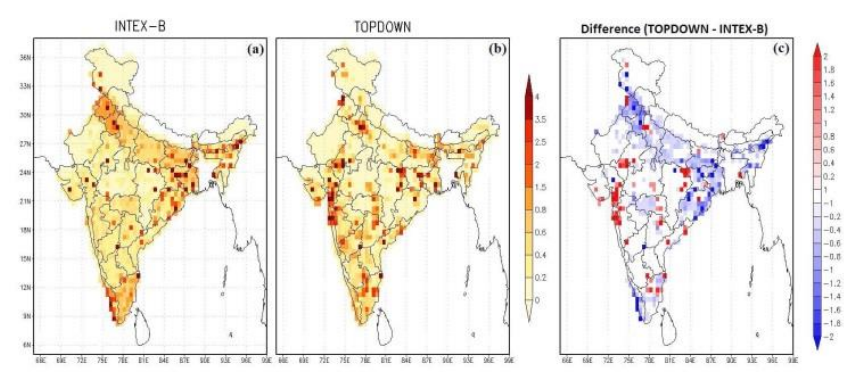

Fig. 5. Satellite constraints of $\mathrm{NO}_{\mathrm{x}}$ emissions in India [8]
As mentioned above, around $50 \%$ of $\mathrm{NO}_{\mathrm{x}}$ emission is from road transportation. As per the studies from Minister of Road Transport, Highways and Shipping in India, old commercial vehicles are responsible for biggest part of the vehicular pollution - Fig. $6[10,14,16]$.



Fig. 6. $\mathrm{NO}_{\mathrm{x}}$ emissions by old vehicles [10]

\section{Some methods of reducing $\mathrm{NO}_{\mathrm{x}}$ emissions}

There are some methods to reduce $\mathrm{NO}_{\mathrm{x}}$, as follow:

- Humid Air Method - in this technique, water vapour is blended in the air before providing it to the cylinder. Air from the turbocharger blower is gone through a cell that humidifies and chills the hot air taking moisture from the cooling water until air immersion is accomplished. This strategy can accomplish diminishment of $\mathrm{NO}_{x}$ by $70-80 \%$,

- Exhaust Gas Recirculation (EGR) - as the name recommends, some measure of exhaust gases is sent back to the search space to stir up with the air to be provided to cylinder for combustion. This lessens the oxygen substance of the air and subsequently decreases development of $\mathrm{NO}_{\mathrm{x}}$ by $50 \%$ even $[1,2,15]$,

- Water Injection and Water emulsion - in this strategy, water is added to lessen the temperature of ignition prompting low $\mathrm{NO}_{\mathrm{x}}$ emanation. In water emulsion, fuel is mixed with water and in water infusion; a different fresh water injector is mounted in the cylinder head that infuses water. This technique has a disadvantage of expanding the specific fuel oil burning with lessening in $\mathrm{NO}_{x}$ by just 20 $45 \%$,

- High scavenge pressure and compression ratio with high rummage weight and compression ratio, substantial measure of air can be acquainted inside the cylinder with bring down burning temperature and $\mathrm{NO}_{\mathrm{x}}$ outflow by $25 \%$,

- Selective Catalytic Reduction (SCR) - is the most productive technique to diminish $\mathrm{NO}_{\mathrm{x}}$ outflows from exhaust gases up to $90-95 \%$. In this technique the exhaust gas is blended by water arrangement of urea and after that it is gone through catalytic convertor. The main drawback of SCR is its cost of installation and working expense.

A generally embraced course to reduce $\mathrm{NO}_{x}$ outflows is Exhaust Gas Recirculation (EGR). Its includes recirculating a controllable extent of the engine exhaust again into the intake air. For controlling the flow of gas there is a valve. EGR reduces $\mathrm{NO}_{\mathrm{x}}$ by the lowering combustion chamber temperatures. Gases represented from EGR frameworks will likewise contain near equilibrium of $\mathrm{CO} \& \mathrm{NO}_{\mathrm{x}}$; the 
small amount initially inside the combustion chamber represses the aggregate net generation of these and different contaminations when tested on a time average.

An appropriately working EGR can hypothetically build the effectiveness of gasoline engine through a various mechanisms:

- reduced throttling losses. There will be increase in the pressure of inlet manifold. At a given power output throttle plate must be opened further because of the inertion of inert exhaust gas to the intake manifold and this make diminishing in throttling losses,

- reduced heat rejection. Brought down peak combustion temperatures not just decreases $\mathrm{NO}_{\mathrm{x}}$ development, it additionally diminishes the loss of thermal energy to combustion chamber surfaces, during the expansion stroke making more accessible for change to mechanical work,

- reduced chemical dissociation. The lower top temperatures result in a greater amount of the discharged energy staying as sensible energy close TDC (Top Dead Centre), instead of being bound up in the dissociation of combustion items. This impact is minor compared with the initial two.

EGR valves are differentiate by the way working or with the working principle. The main types are:

- mechanical controlled,

- electronic controlled,

- working with vacuum,

- combination of vacuum \& pressure.

EGR valve designs also differs from petrol powered and diesel powered. Nowadays, the modern vehicles uses different type valves configuration with electronic one as dominant. But in old engines, a vacuum hose is connected to carburettor or throttle body to the valve.

\section{Fabricating and implementing EGR}

As going through the surveys and statistics, found that old cars are the main source of $\mathrm{NO}_{\mathrm{x}}$ emission. For reducing $\mathrm{NO}_{\mathrm{x}}$, fabricating EGR in old vehicle is the best solution.

For fabricating an EGR in old engine, the first and main task is selection of a car. Its confusing task to select a particular as far so much brands are there. So, came to solution of selecting a base model, means an engine had only basic specifications. As far we can make alterations depends upon engine specification. However, by selecting base model engine's EGR mechanism will be suite for all engines.

During the period from 1983 to 2014, a city car ruled Indian streets called Maruti 800 is a produced by Maruti Suzuki. With more than 30 long periods of generation, this became the second longest creation auto in India, next just to Ambassador by Hindustan motors. It is reverently called as "The Car that put India on Wheels". The first generation (SS80) had an 800cc F8B engine and depended on the 1979 Suzuki Fronte. A modernized aerodynamic version utilizing the shape of the second generation (SB308) was displayed in late 1986.

Generally viewed as the most leading car in India, Maruti sold around 2.66 million in India itself out of 2.87 million 800s manufactured. Before the entry of Maruti Alto at 2004, Maruti 800 persist as top of the line auto in India. It was likewise sent out to various Asian countries includ- ing, Bangladesh, Sri Lanka and Nepal and was additionally accessible in Morocco and sold in European markets as the Maruti Suzuki.

Table 1. Maruti 800 engine specification

\begin{tabular}{|c|c|}
\hline Cylinders & 3 \\
\hline Displacement & $796 \mathrm{~cm}^{3}$ \\
\hline Type & Water Cooled SOHC Petrol \\
\hline Valve train & 2 valves \\
\hline Bore \& Stroke & $68.5 \times 72.0 \mathrm{~mm}$ \\
\hline Max Power & 37 BHP@5000 rpm \\
\hline Max Torque & $59 \mathrm{Nm} @ 2500 \mathrm{rpm}$ \\
\hline
\end{tabular}

To fabricate a fully functioning EGR system in a chosen engine the EGR line was design with all necessary components. So, there were made:

- recognition of fluid flow using Bernoulli equation, giving information about the balance between elevation, velocity and pressure in duct of EGR line,

- electronics platform with Arduino Open Source to manage signals from varies sensors and actuators. This project uses an Arduino Leonardo microcontroller board to take sensor readings for calibration and for control of servo using various sensor inputs [3],

- time-financial analyses

The design of the EGR line (Fig. 7) is simply based on the fact that the design must be simple, purposeful and efficient. The conventional EGR valve is 2 input 2 output 4-way valve, which is situated between the two manifolds the valve operates and opens the separation between intake and exhaust manifolds causing a part of the exhaust gas to mix with the intake air. Normally this valve is operated mechanically owing the temperature of the gases. The mechanical system consists of valve that operates based on exhaust manifold pressure and intake manifold pressure. However later electronically operated EGE valves are introduced. But the conventional EGR valve cannot serve our purpose, so we introduced a two-way valve operated between on and off in 90-degree angle. The valve is operated using a servomotor, which rotates according to the signal of the controller.

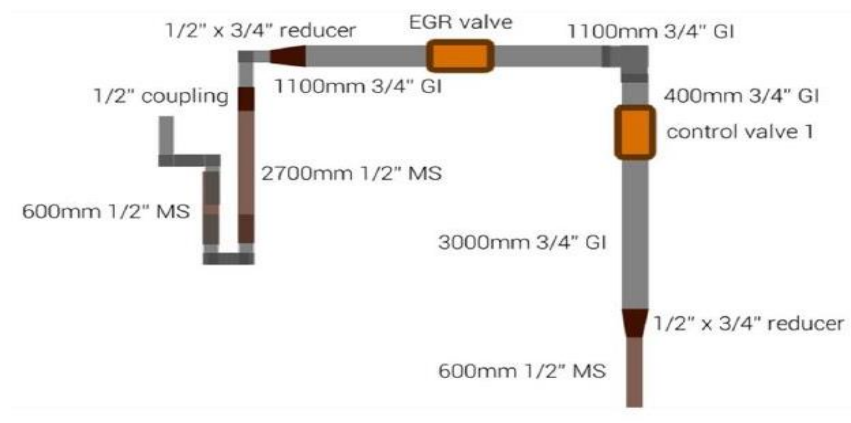

Fig. 7. Design of EGR line for Maruti 800 engine

The sensors characteristic curves were obtained by analysing their signal output values using the Arduino Leonardo microcontroller board. So, there were tested and analysed sensor characteristics: 
- throttle positon sensor (TPS)


Fig. 8. Throttle Position Sensors with analog output vs. rpm

- manifold absolute pressure sensor (MAPS)


Fig. 9. Manifold Absolute Pressure Sensors with analog output vs. rpm

- oxygen sensor/lambda sensor
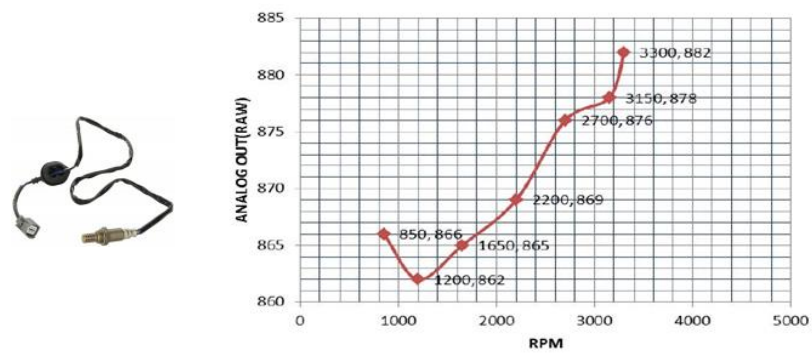

Fig. 10. Oxygen / Lambda Sensors with analog output vs. rpm

- mass air flow sensor (MASF)


Fig. 11. Mass Air Flow Sensors with analog output vs. rpm

- EGR valve control and electronics


Fig. 12. EGR valve with Arduino code for motor control
EGR valve is a simple modified globe valve (open when parallel), i.e. for a 90-degree sweep, the valve is fully open. Since approximate flow through the EGR line is about $30 \%$ (approximately one-third the flow from the main exhaust pipe), a 45 degree sweep is enough to obtain the $15 \%$ flow rate [17].

The control algorithm was developed after careful study of the sensor characteristics of throttle position sensor, manifold absolute pressure sensor and the lambda sensor and then carefully fixing the range of operation of the servo motor $[3,6]$.

The final circuit - the all in one data logging and control module enables simultaneous data logging from all four sensors along with the control of the servo while comparing these values. The final circuit is a combination of the calibration and servo control circuits, with the addition of a dual 7-segment LCD display connected to the circuit so that the current EGR percentage may be displayed. The displays are connected in a multiplexed manner due to the fact that only a limited number of input/output digital pins are available in the Arduino Leonardo microcontroller board. The MAF sensor requires an additional $12 \mathrm{~V}$ supply, which may be taken directly from the engine battery. Due to safety reasons, the supply is taken from a $12 \mathrm{~V}, 1 \mathrm{~A}$, SMPS, DC adapter so that the components on the breadboard are saved from high values of current.

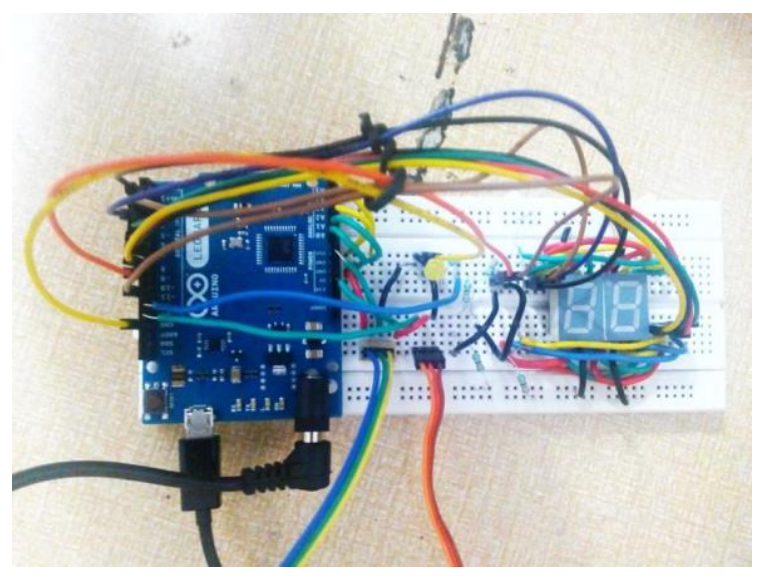

Fig. 13. Breadboard implementation of the final circuit

\section{Estimating the cost and time period for fabricating EGR to all old cars in India}

India is a big country having 29 states and 7 union territories. So the cost of materials \& labour cost is differs from state to state. So taking the average of from all state.

To counting fabricating cost it was taken Indian Rupees (INR) to European Currency (Euro) exchange stock as given on August 15 ${ }^{\text {th }}, 2018: 1$ Euro $=79.30$ INR.

\section{COSTS}

- Material cost

There were estimating the cost of materials for fabricating EGR on Maruti 800. It will change with the car. So here, also the mean price was considering.

AURDINO LEONARS board: it was used AT mega 32u4 $(5 \mathrm{v})$. Its input volts is $7-12 \mathrm{~V}$ flash memory of $32 \mathrm{kB}$ with 500 INR (6.31 Euro).

INLET SECTION: the main component are: 
Solving the problem of air quality in Indian cities by retrofitting the EGR

Convergent-divergent section

Convergent nozzle

Total for inlet section

$=110 \mathrm{INR}(1.39$ Euro)

$=120 \mathrm{INR}(1.51$ Euro $)$

$=230 \mathrm{INR}$ (2.90 Euro)

EGR LINE: it needs so much nibbling, elbow pipe, reducer extra.

\begin{tabular}{|l|c|}
\hline Item & Price (in INR) \\
\hline $1 / 2 "$ MS extender & 105 \\
\hline $3 / 4 "$ to $1 / 2 "$ Reducer & 110 \\
\hline $3 / 4 "$ GI nibbling & 85 \\
\hline 3/4" GI short elbow & 100 \\
\hline 3/4" GI elbow & 110 \\
\hline $3 / 4 "$ to $1 / 2 "$ Reducer & 110 \\
\hline $1 / 2 "$ MS short elbow & 120 \\
\hline Total & $740(9.33$ Euro $)$ \\
\hline
\end{tabular}

For EGR valve, Techno 2W-200-20-3/4". It costs 1810 INR (22.82 Euro) [17].

Manual Over Ride Valve of Aira Euro Automation's costs 700 INR (8.83 Euro).

At last, for brass nozzle is 310 INR (3.91 Euro).

Therefore, for making EGR line the total price is 3560 INR (44.98 Euro).

\section{SENSORS}

Sensors mentioned above have got process as follow:

\begin{tabular}{|l|c|c|}
\hline Name & Brand/Model & Price (in INR) \\
\hline $\begin{array}{l}\text { Throttle Position } \\
\text { Sensors }\end{array}$ & Generic & 2200 \\
\hline $\begin{array}{l}\text { Manifold Absolute } \\
\text { Pressure Sensors }\end{array}$ & Generic & 1850 \\
\hline $\begin{array}{l}\text { Oxygen/Lambda } \\
\text { Sensors }\end{array}$ & Denso & 4650 \\
\hline $\begin{array}{l}\text { Mass Air Flow } \\
\text { Sensors }\end{array}$ & Generic & 3100 \\
\hline Total & & 9820 (123.83 Euro) \\
\hline
\end{tabular}

\section{- miscellaneous expenses}

So much of small, but important things we need. For example, electric wires, connectors, adapters, screws, bolt\& nuts etc. The expense for tools also included here. We can use same tools for so many cars. Here we took as average. It's also include electricity charge, welding cost, water bills etc. So for all, as an average we count 500 INR (6.31 Euro) for one car.

\section{- labour cost}

For fabricating an EGR, we need a technical crew having: one Automotive Engineer, one Electronics and Communication Engineer, one Quality inspector, two Professional Welders, three Automotive Mechanic and for management level - one person should be there as supervisor or as district head. One head for a state with one assistant \& one main head for all country with three assistant. The salary structure for the District, State \& National heads we don't need to hire new person, can give extra duty to: Regional Transport Officer (District Level, State Transport Commissioner (State Level), Transport Research Advisor (National Level).

\begin{tabular}{|l|c|}
\hline Designation & Salary (in INR) \\
\hline Automotive Engineer & $1000 /$ car \\
\hline E \& C Engineer & $55,000 /$ month \\
\hline Quality Inspector & $650 /$ car \\
\hline Professional Welder & $350 /$ car \\
\hline Automotive Mechanic & $350 /$ car \\
\hline State level Assistant & $35,000 /$ month \\
\hline National level Assistant & $50,000 /$ month \\
\hline
\end{tabular}

\section{TIME}

In India, maximum period of one car according to tax payment is 15 years. After that, they need re-registration and that time they should have to follow the current emission standard. In addition, the Baharat stage 4 emission standard was introduced in 2010.

Now it is 2018, so we considering the cars and taxis between 2004 and 2010.

Number of cars from 2004 to $2010=71,911,501$

Number of taxis from 2004 to $2010=10,048,572$

Total number of cars $\quad=81,960,073$ vs. more than $210 \mathrm{mln}$ grand total (including buses, two-wheelers, jeeps, goods vehicle etc.).

As result of research, we are cutting $50 \%$ of cars from this because in some of taxis are heavy vehicles, and in cars some are dumbed, were destroyed in accident, some are unusable. Therefore, the final count of cars are 40,980,037.

India have 718 districts. For the speedy output opening seven station in a district is the better number, so, $718 \cdot 7=$ 5,026. However, the big cities like Mumbai, Delhi, Ahmedabad, Pune, Chennai, Vizag, Hyderabad, Lucknow, Jaipur, Kolkata, Kochi, Amritsar have enormous amount of cars. We have to open more than one station in all cities. Therefore, we came to decision for 7,200 total stations. An average of eight cars can be fabricate in one station. Total 57,600 cars per day. So number of days we need to fabricate all cars 40,980,037/57,600 $=711.45$ days. In years (including weekends and holidays) 711.45/216 $=3.3$ years to retrofitting all old cars in India.

\section{Conclusions}

Citizens of India as others aimed to make India unpolluted. Initiated a research for it and results in a finding that NOx is the most deadliest pollutant from cars especially from old cars. As a solution decided to reduce $\mathrm{NO}_{\mathrm{x}}$ emission from old cars by retrofitting EGR system in it, which is considered as the best remedy for $\mathrm{NO}_{\mathrm{x}}$ emission. It was done for base model and a most popular car Maruti 800 . The fabrication was very successful with very cost.

The total cost for implementing an EGR in a car is 14,850 INR (188 Euro) without the labour charge. Government of India can implies a subsidy scene to poor car owners and take surcharge from the owners having high annual income. This make the cost of fabrication in a tally. We need total 5026 working station for 40.9 million cars. By fabricating 57,600 cars per day, we can implement EGR in all cars within 3.3 years, but of course, another portion of old vehicles comes every year.

As a conclusion, we can say within 2 years we can control the $\mathrm{NO}_{\mathrm{x}}$ emission to a great extent. As the results of this, the air pollution of India will reduce and Indian cities 
shall be eliminated from the list of most polluted cities in world. Before 50 years, India was the one of the country with good air quality, as per my research we can make it again.

\section{Bibliography}

[1] ABD-ALLA, G.H., Using exhaust gas recirculation in internal combustion engines: a review, Energy Conversion and Management. 43, 2002.

[2] ALGER, T. Clean-and-cool: cooled EGR improves fuel economy and emissions in gasoline engines. Technology Today. Summer 2010.

[3] Arduino and coding, www.arduino.cc

[4] DUTTON, J.A., Products of combustion, energy conservation and environmental protection, www.e-education. psu.edu/egee102/node/1951.

[5] European Union emission inventory report 1990-2016, www.eea.europa.eu/publications/european-union-emissioninventory-report-1.

[6] Exhaust gas mass flow sensor for applications in commercial Diesel engines: the system for optimizing the emission characteristics. Kolbenschmidt Pierburg Group. www.powerparts.it/eger_valves.pdf

[7] GAMBLE, E., TERRELL, D., DEFRANCESCO, R. Nozzle selection and design criteria. 40th AIAA/ASME/SAE/ ASEE Joint Propulsion Conference and Exhibit Fort Lauderdale. 2004, DOI:10.2514/6.2004-3923. arc.aiaa.org/ doi/10.2514/6.2004-3923.

[8] GHUDE, S.D., PFISTER, G.G., JENA, C.K. et al. Satellite constraints of nitrogen oxide $\left(\mathrm{NO}_{\mathrm{x}}\right)$ emissions from India based on OMI observations and WRF-Chem simulations. Geophysical Research Letters. 2013, 40, 423-428, DOI: 10.1029/2012GL053926.

[9] GRISSO, R., HIPKINS, P., SHAWN, D. et al. Nozzles: selection and sizing. Virginia Cooperative Extension. Publication 442-032. 2013.

\begin{abstract}
Zbigniew J. Sroka, DSc., DEng. - Faculty of Mechanical Engineering, Wroclaw University of Science and Technology.

e-mail: Zbigniew.Sroka@pwr.edu.pl
\end{abstract}

\author{
Marek Reksa, DEng. - Faculty of Mechanical Engi- \\ neering, Wroclaw University of Science and Tech- \\ nology. \\ e-mail:Marek.Reksa@pwr.edu.pl
}


Chandu Valuvila Thulasidharan Pillai, MEng. Faculty of Mechanical Engineering, Wroclaw University of Science and Technology.

e-mail: Chandu.T.Pillai@gmail.com
[10] GUTTIKUNDA, S.K., MOHAN, D., Re-fueling road transport for better air quality in India. Energy Policy. 2014, 68, 556-561, DOI: 10.1016/j.enpol.2013.12.067.

[11] KECH, J., SCHMIDT, G, PHILIPP, G. et al. Exhaust gas recirculation: internal engine technology for reducing nitrogen oxide emissions. Engine technology, www.mtuonline.com.

[12] Nitrous Oxide Cycle Diagram, www.airpollution411.blogspot.com.

[13] OO, T., OT, T., Effect of exhaust gas recirculation on performance of petrol engine. Research\&Reviews: Journal of Engineering and Technology. 2017, 6(2), 14-17.

[14] Road Transport Year Book. Statics and details of vehicles registration in India https://data.gov.in/catalog/road-transport-year-book-2013-14-and-2014-15.

[15] SHAHADAT, M.M.Z., NABI, M.N., AKHTER, M.S. et al. Combined effect of EGR and inlet air preheating on engine performance in Diesel engine. International Energy Journal. 2008, 9, 109-116.

[16] Survey and statics for air pollution \& fatalities from World Health Organization, www.who.int/airpollution/en/

[17] Types of EGR valves and sensors. documents.tips/documents/ hyundai-motor-company-new.html\&www.egrsensors.com.au

[18] WALKE, P.V., DESHPANDE, N.V., BODKHE, R.G. Impact of exhaust gas recirculation on the performances of Diesel engine. Proceedings of the World Congress on Engineering. 2008, II.

[19] World's first estimation of long-term variations in global atmospheric pollutant emissions based on data assimilation. Nagoya University, 27.01.2017, www.jamstec.go.jp/e/about/ press_release/20170127.

Wojciech Walkowiak, DEng. - Faculty of Mechanical Engineering, Wroclaw University of Science and Technology.

e-mail:Wojciech.Walkowiak@pwr.edu.pl

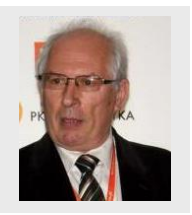

Czesław Kolanek, DEng. - Faculty of Mechanical Engineering, Wroclaw University of Science and Technology.

e-mail: Czeslaw.Kolanek@pwr.edu.pl 